\title{
A Forgotten Moment in Education Policy A Hungarian-Swedish Case Study from the Early 1970s
}

TAMÁs KoZMA ${ }^{* 1}$ AND Zoltán TóZsÉR ${ }^{2}$

$\approx$ After the brutal uprising of 1956, there was a decade of gradual reform in Hungary under the Kadar regime. As part of this decade of reform, Hungary received permission to join the IEA (International Association for the Evaluation of Educational Achievements), an organisation that had been established in the late 1950 o by the well known Swedish educator and researcher Torsten Husén, who played an intermediary role in education policy between the West and the East. One step in fulfilling this role was his initiation a summer school under the umbrella of the IEA in the Swedish resort area of Graenna. The Hungarians were the only delegates from behind the Iron Curtain to participate. For them, it was a unique experience to view the centralised Swedish welfare state with contributions of American liberal democracy and education. This summer school of 1971 has since been forgotten, yet most of the initiatives of education policy after the political turn of 1989/9o have their roots there. This is especially true of the work and career of the well known Hungarian educator and a follower of Husén, the late Zoltán Bathory.

Keywords: Central and Eastern Europe, Educational reform, IEA, Torsten Husén, Zoltán Bathory

$1 \quad{ }^{\star}$ Corresponding author. The University of Debrecen, Egyetem tér 1, 4032 Debrecen, Hungary kozmat@ella.hu

Personal Website: http://cherd.unideb.hu/kozmatamas

2 The University of Debrecen, Egyetem tér 1, 4032 Debrecen, Hungary

tozser.zoltan@arts.unideb.hu

Personal Website: https://sites.google.com/site/nevtudtozser/ 


\section{Pozabljen trenutek v edukacijskih politikah Madžarsko-švedska študija primera iz zgodnjih 70 . let prejšnjega stoletja}

TAmÁs KozMA* IN ZoLTÁN Tőzsér

\& Po brutalni vstaji leta 1956 se je na Madžarskem v času Kadarjevega režima začelo desetletje postopnih reform. V tem desetletju je Madžarska dobila tudi dovoljenje, da se pridruži IEA (International Association for the Evaluation of Educational Achievements), organizaciji, ki jo je v poznih petdesetih letih prejšnjega stoletja ustanovil znani švedski pedagog in raziskovalec Torsten Husén, posrednik med zahodnimi in vzhodnimi edukacijskimi politikami. Eden od korakov k doseganju tega poslanstva je bil tudi pobuda za poletno šolo, ki je potekala v okviru IEA, in sicer na območju Graenna na Švedskem. Madžari so bili edini udeleženci, ki so prihajali iz držav za železno zaveso. Za njih je bila to edinstvena priložnost, da so spoznali centraliziran švedski primer socialne države, nastale po vzoru ameriške liberalne demokracije in $\mathrm{z}$ izobraževanjem. Poletna šola iz leta 1971 je bila pozneje sicer pozabljena, a večina pobud $\mathrm{v}$ edukacijskih politikah po političnem preobratu leta 1989/1990 izvira prav od tam. To še posebej velja za delo in kariero dobro znanega madžarskega pedagoga in privrženca Huséna, pokojnega Zoltána Bathorya.

Ključne besede: Edukacijske reforme, osrednja in vzhodna Evropa, IEA, Torsten Husén, Zoltán Bathory 


\section{In Memory of Zoltán Bathory and those Hungarians} who participated in the 1971 summer school

\section{Introduction}

A "new era of Hungarian education policy" started in the late 1960 s and early 1970s, when the Kadar regime, doing away with the severe international isolation of the late 1950 s and early 1960s (after the 1956 Hungarian Revolution), undertook its most intensive period of reform, the peak of which was in the 1968 economic reform. Even though the reforms of the 1960 s ended at the turn of the decade, in certain fields of public administration, such as education policy, the spirit of reform survived the fall of the reform period. This reform period came to an end with the acceptance of the 1972 Education Policy Act, which was, however, considered by the participants as a continuation of the reform period (see Pukánszky \& Németh, 1997, pp. 673-675). This period of education reform is an unexplored area of research. However, for the generations of those who are no longer creators of education policy, this period was one of the most relevant experiences of education policy (the other one being the political changeover in 1989/1990).

This early reform generation, which consisted of young scholars, experts and education policymakers, contributed to the intensive development of the education policy and education reform of the Kadar regime, actually surpassing similar reforms in neighbouring countries. At the same time, this development contributed to the unique political environment of the Kadar regime, that is, to the illusion of "liveable socialism". An historical examination of this period of education reform - the late 1960 s and early 1970 - has not yet been undertaken. Therefore, the present study, based on personal memories and knowledge, aims to contribute to the understanding of this period, and to illustrate the research with personal examples. Moreover, the aim is to perpetuate the role and activities of two outstanding figures of this education reform, Árpád Kiss and Zoltán Bathory. The topic of the study is a unique summer university. Similar summer universities were organised in other disciplines at the end of the 1960s, but in the field of educational research it was quite unusual.

This summer university of the International Association for the Evaluation of Educational Achievement (IEA) was organised by the United Nations Educational, Scientific and Cultural Organisation (UNESCO). However, it was not directly in line with the mainstream of Hungarian educational research because it was a foreign initiative. The summer school not only had a long term impact on the participants' lives, but also laid the groundwork for a flourishing 
period of educational assessment in Hungary. In fact, its effects are still evident in educational assessment today. The first part of the present study focuses on the preparations for the summer seminar. The second part elaborates on the events of the seminar, while the last part is an evaluation of the direct and indirect effects, as well as long term effects, of the seminar. During the preparation of the study, only the most essential research was carried out; the study is primarily based on personal experience aimed at preparing an educational history research project.

\section{Preparations}

The summer seminar, in which Hungarian scholars and researchers took part for the first time since the 1956 revolution, was organised by UNESCO's IEA programme. Its long history dates back to Hungary's role in the IEA programme. The IEA programme was initiated by Torsten Husén at the beginning of the 1960s (Walker, 1976). Husén not only became the emblematic figure of Swedish, and later international, educational research but, more importantly for the present study, he also became a symbolic figure of Swedish social democratic movements and an interposer between East and West. Olof Palme might be considered the leading figure of the Swedish social democrats in the history of international politics. In fact, Olof Palme, as a young education minister, and Torsten Husén, as his older advisor, contributed significantly to the establishment of this unusual Eastern European educational cooperation.

The IEA programme was based on a particular scholarly interest initiated by applied psychologists interested in students' school results. Education statisticians made an attempt to use these data for international comparisons. Here we highlight only two figures who established and stimulated this scholarly interest. The first was sociologist James Coleman, who, supported by the American Congress, prepared a well known report in 1966 about social injustice in America (Coleman, 1966). In his report, Coleman not only used the results of IQ tests (as had his predecessors, such as Jensen, 1969), but also the results of student assessments that at that time were widespread in US education policies and educational research. It seemed to be logical to use the results of these student assessments not only for social science research (international mobility research), but also for education comparisons.

The second outstanding figure was Philip Coombs, who joined Kennedy's group of reform economists, launching and propagating international educational planning. This initiative did not become very popular in the USA; however, UNESCO supported the idea and regarded it as its main activity in 
the 196os. In his renowned work (Coombs, 1968), Coombs reported on the "world crisis of education". He intended to solve this through educational planning (today known as "strategic management"). All of this occurred at a time when former colonial countries were gaining "independence", and it became a well known fact that the education system, or more precisely literacy, was at a desperately low level in these countries. For UNESCO, this was a stimulus for supporting educational planning as a miraculous remedy, for emphasising the importance of educational planning, for establishing organisations and for launching training on the international level, as well as on the level of developing countries. The background to this movement was the international political situation of the 196os, especially the Vietnam War and the youth movement associated with it. The movement of the 1960 s peaked in Europe in the student riots of 1968, and it is well known that this influenced socialist countries behind the Iron Curtain. Although it is not usual to find a direct link between these movements, the peak was definitely the Prague Spring of 1968, surrounded by several retainer countries and police autocracy, as well as the first generation of youth bands, amongst other phenomena.

Torsten Husén's initiative to measure and collect student achievement in the 1960 os both on the European and international levels was part of this movement, or, more precisely, it signified an increased appreciation of the role of youth and of education policy. Husén's first research, later called a pilot study, was a comparative study on student mathematical achievement in twelve countries between 1963 and 1967 (Husén, 1969). The success of this research and the positive evaluation of the results of education policy motivated Husén and his colleagues - particularly his young British colleague Neville Postlethwaite - to continue their research on the international level, and the IEA survey was therefore organised. This survey included 19 countries, with the only communist country being Hungary. The data of the Six Subject Study were gathered in the period 1970-71, and the analysis was published two years later (see Comber \& Keeves, 1973).

\section{Signs of a New Political Era}

The 5th Educational Congress was one of the outcomes of the changes in education policy in the 1960 s, at least so practitioners and educational leaders thought (Kiss, 1970). Some of the institutions of Hungarian education science (the Hungarian Pedagogical Society and the journal Hungarian Pedagogy) that had been shut down, or at least "cancelled", in 1949 reopened and started operating again (under the supervision of the Teachers' Trade Union). The National 
Pedagogical Institute, which was established in 1962 as a background institute of the Education Ministry and its Didactics Department (the director was Pál Bakonyi, and later Árpád Kiss) proved to be an appropriate institute to join in the international student assessment programme. The Didactics Department seemed to be a good fit for this purpose, because the Department's colleagues expressed their willingness to be leaders of the Institute. They were representatives of a didactics that could be used by methodology departments (developers of school subjects) in their taught subjects. Amongst the issues and the applications of this coordination role was the measurement of student achievements and assessment of student results.

This was stimulated mainly by the commitment of Árpád Kiss (Kiss, 1969), a commitment that was raised to an international level by participating in the IEA. From the very beginning, the role of the Didactics Department generally the testing of student achievement - was looked upon with suspicion within the Institute, and even more so outside the Institute. The role of experimental psychology and psychologists was judged and prejudiced in the light of the general professional opinion; they only started to return to public educational life in the 1960s (Pléh, 1992). Several partners of the Didactics Department - university and college departments - did not like the idea of measuring student achievement only using tests. Instead, they supported a new approach to educational research, that of cybernetics. Members of the Didactics Department did not reject this idea, but they were rather sceptical about it. This was especially true of teachers of methodology, whereas teachers of the sciences (such as physics) were more open to the idea.

The only exception was the Education Department of the University of Szeged. Due to his knowledge of foreign languages, its leader György Ágoston was a member of the board of directors of UNESCO's Hamburg Institute, and was therefore informed about IEA projects. He represented Hungary's participation, and made every attempt to represent his department in the IEA project. His colleagues in the department were more open to the renewal of didactics than those in Budapest or Debrecen. For more than three decades, the main representative of this openness was József Nagy. He founded the socalled School of Szeged, which focused on educational research (Nagy, 1966). Zoltán Bathory, who was a promising and ambitious colleague of the Hungarian Pedagogical Institute (OPI), gained his doctorate under Nagy's supervision. After Árpád Kiss succeeded in arranging the Hungarian Pedagogical Institute's involvement in the IEA project, Zoltán Bathory was charged with overseeing Hungary's participation in the project. 


\section{The Summer School in Graenna}

Torsten Husén and his colleague Neville Postlethwaite visited Budapest several times to prepare Hungary's inclusion in the IEA project (Kozma, 1969). Later, these visits were reciprocated, with the OPI group travelling to the summer university of Graenna, Sweden. It took years for the colleagues at OPI to prepare this participation in the IEA project; however, the present writer has no written documentation about this. Árpád Kiss and Zoltán Bathory made careful preparations when selecting the representatives of Hungarian educational research, negotiating this with both Budapest and Stockholm.

They intended to find those Hungarian educational researchers, preferably methodologists, who were prepared, mainly through their language knowledge and skills, to meet the requirements of an international summer seminar. They all had to represent the subjects in which they could carry out research in their later academic carriers. Last but not least, they all had to meet the requirements of Hungarian politics. The members of the Hungarian team were selected by the beginning of 1971. It was led by Zoltán Bathory, who always remained a committed member of the IEA and later became a representative of student assessment both on an international and national level. Endre Ballér originally conducted research in the field of education history and later, in the 1960s, worked for the Education Ministry of Hungary. He was responsible for developing curriculum theory and curriculum planning (mainly because of his knowledge of languages).

József Horváth was a member of OPI's foreign languages department and was well known as an English teacher. The team not only used his knowledge of language teaching but also his ability to use language. Péter Szebenyi represented the humanities (social sciences), while Lajos Varga represented the sciences (such as physics). Tamás Kozma represented primary school education, partly because of his studies and experience in the field and partly because of his connections with the media. At the beginning of 1971, it seemed impossible, at least within the field of educational research, to send six educational researchers to an international seminar in the West lasting several weeks without any observers from the Ministry, although it is true that their family members stayed in Hungary. With his influence and connections, Árpád Kiss was considered to be the key person to undertaken this very significant achievement. After some meetings and networking events, the team set off on their journey to Sweden in the first days of July 1971.

Graenna was selected as the place for the summer university because of its ideal location. Participants of the summer seminar arrived from 18 
countries. The Graenna Summer University was organised by UNESCO, who supported the IEA and its events for delegates of developing countries not only on a professional basis but also on a political basis. For East-Central European countries, namely Poland and Hungary, the 1971 summer university was the only "window" on Western Europe under UNESCO. The 1971 summery university in Graenna, however, was originally organised by Torsten Husén, who used his East-West connections and cultural diplomacy skills. Husén originally graduated from a German university, which is why he interpreted education from this point of view; however, later in his academic carrier he showed an interest in applied educational research. Husén became a well known educational researcher (Husén \& Postlethwaite, 1988). Even though Husén and his institute initiated and organised the summer university in Graenna, the seminar was actually sponsored by the School of Education of the University of Chicago; the Graenna Summer University was advertised as a summer course of the School of Education of the University of Chicago. The summer course covered several topics, but the main focus was on how to measure student achievement and how this could contribute to improving education policy. The course focused on applied educational research and how the results of such an approach might contribute to developing education policy.

The education professionals visiting Sweden at that time might have noticed some differences and specific characteristics in the Swedish education system and in its educational research. Firstly, Sweden did not have a central education system such as Budapest, Moscow or Paris. There were several educational research projects in progress, carried out by universities and above all by teacher training colleges. The majority of these projects involved contract-based research. The Swedish Royal Office, that is, the Education Ministry, was the contractor, organiser and supporter of Swedish educational research. The Education Ministry was the owner of curricula and "education plans", at least as far as the content was concerned, as well as the concept of curricula and planning. Research conducted by Swedish educational researchers was totally different from that in Hungary. Not only were the history and philosophy of education completely omitted, but "best practices" in education were also excluded. Instead, Swedish educational research focused mainly on psychological and social science research. The data gained from this research seemed to be directly applicable to education policy.

Leaders of Swedish education policy also participated in the summer seminar in Graenna, with one of the most outstanding figures being Olof Palme. The Graenna Summer University was a combination of American and Swedish approaches to educational research and educational planning. Swedish 
educational researchers had an opportunity to become acquainted not only with American educational research but also with the educational research of developing countries, as most of the participants in the 1971 Graenna Summer University were from developing countries, that is, from post-colonial countries. This was one of the greatest achievements of Swedish cultural diplomacy. Only two countries from East-Central Europe - Poland and Hungary - participated in the Graenna Summer University. Politics was avoided at the Graenna seminar not only for defensive reasons, but also because of professional beliefs. Student achievement could be related to education policy, not to politics. The focus was instead on educational research; more precisely, on cognitive psychology (Kagan \& Havemann, 1968) and on psychological statistics (Hajtman, 1971).

\section{Life and Work at the Summer School}

At the Graenna seminar, Plenary sessions were held in the mornings, at which professors and educational researchers presented their own books and studies for discussion purposes. These academic sessions were perfect opportunities to become acquainted with the educational research approaches of the "Chicago School". Torsten Husén's lectures focused on the problems of educational research and policymaking in the Swedish education system. The book he presented (Husén \& Boalt, 1967) was an educational case study of Sweden. Although it was not this book that gained Husén his reputation, but rather the book entitled Talent, Opportunity and Career (Husén, 1969), on this occasion the latter was not appropriate for the seminar because it reflected the author's beliefs on education rather than his concepts on education policy. The book he presented was a co-authored collection of studies that concentrated on Swedish education reform. Husén firmly believed, and made his audience also believe, that if educational research is conducted in an excellent way, and if the results of such research are presented properly, it can have an influence on education policy. Havighurst, who was well known for his publications (Havighurst, 1962, 1966), represented the sociological approach in the Chicago team, stressing the importance of education in the social context. He had elaborated his thoughts in his book entitled Education and Society (Havighurst \& Neugarten, 1962). Combining cultural anthropology and social psychology, his approach focused on education as one of the key forms of the socialisation process, and on its influencing factors, such as the family, school, the work place and leisure activities. During the sessions of the summer seminar, Havighurst argued that the sociology of education is in fact the sociology of human development. 
Ralph Tyler summarised the main points of his book entitled Basic Principles of Curriculum and Instruction (Tyler, 1970). Tyler, however, did not interpret the curriculum as a "central education document", as Hungarians did, but rather as a document that is based on "student needs". This interpretation of curriculum seemed quite unusual to the Hungarians, who were used to socialist curricula (where the curriculum was the "law"), and curricula based on principles and values, not on student needs. However, as it later turned out, the message of the summer seminar could only be interpreted and later applied in Hungary by using Tyler's approach to the curriculum. The philosophy and techniques of measuring student achievement could not be understood without this radically new interpretation of the curriculum and education.

Benjamin Bloom, who was one of the most influential figures of the seminar, presented different ways of measuring student achievement (Bloom et al., 1971). Bloom's lectures and the ensuing discussions not only elaborated the origins of measuring student achievement but also gave a detailed account of this approach with regard to the activities of the School of Education of the University of Chicago. Bloom commenced his career as a psychologist and later worked for the university's Centre for Assessment. He was responsible for undertaking numerous student assessments, and therefore began to implement new ways of analysing curricula, namely formative and summative assessments, an approach that gained him an international reputation. His approach can be used in classrooms as well as for school assessments. Benjamin Bloom definitely contributed to the success of the "Chicago School". There were two plenary sessions in the mornings and seminars in the afternoons. In addition to teachers, "the faculty" also had evening meetings every week to evaluate their own achievements during the seminar.

The schedules of the afternoon seminars were different from the morning plenary sessions. "Delegates" of the participating countries formed teams according to their professions and functions in the afternoon seminars. Zoltán Bathory joined the so-called scholarly team, which was led by Postlethwaite. Bathory and Postlethwaite became friends, and Bathory was therefore one of the leading researchers of their team. Endre Ballér became a member of an administrative group that was responsible for developing curricula using the results of IEA surveys and international comparisons. Péter Szebenyi and Lajos Varga took part in subject groups, while Tamás Kozma participated in a group of primary school researchers. 


\section{The Impact of that Summer}

Even though the Hungarian educational research team participated in Graenna with the official consent of the ruling political party of Hungary, the initial effects of the seminar were few. However, members of the Hungarian team reached agreement on how they would publish what they had learned at the seminar in Graenna. In truth, this was not just a voluntary undertaking but also a formal obligation on their part. To meet this demand, the Hungarian scholars published several reviews in the official journal of the Hungarian Pedagogical Institute (The Pedagogical Review) about the books that had been presented at the seminar in Graenna (Kozma, 1972). However, the participants of the summer seminar faced two challenges: the first emerged from language differences, while the second was derived from the different concepts and ideas about education. It was not always possible to express and discuss the meanings of education terms in Hungarian, terms that otherwise sounded natural in English. This was not only because of linguistic differences, but mainly because of conceptual differences. For instance, the terms curriculum or formative and summative assessment had different meanings and connotations in Graenna than in Budapest. Moreover, assessment had a different meaning, resembling measurement.

The second challenge was the interpretation of education policy. Although the 1960 s was a great decade for educational research, pedagogical knowledge and beliefs from the 1950s remained quite influential in public opinion about education. Members of the Graenna team, all but one of them colleagues at the Hungarian Pedagogical Institute, not only published book reviews about Graenna, but also critiques. Even if all of the reviews had been critiques, the team could not have made a significant impact on Hungarian educational research and education policy; Graenna was a forbidden issue for several years, and it was not possible to discuss the knowledge and experiences gained at the summer seminar in Graenna.

The seminar did, however, prove to be very influential in the long term, which was inevitable given the case of the IEA. The Graenna seminar was the first influential conference of the IEA, and was followed by several other important events. The Graenna team was only one episode in the history of the IEA, and even though the IEA was later closed down, it still continues to influence educational research. PISA research, as well as Hungarian Higher Education Student Achievement Research, can be regarded as direct descendants of the IEA, and of the 1971 Graenna summer seminar. Participation in the IEA Graenna seminar influenced the academic careers of all Hungarian educational 
researchers, because at the time it appeared to be the mainstream of international educational research (an assumption that later proved to be false). Zoltán Bathory's academic carrier was fundamentally influenced by the Graenna seminar and his connection to the IEA. He not only extended his professional knowledge and academic relations but also strengthened his position in the Hungarian Pedagogical Institute and in the Hungarian educational research community in general.

Bathory was strongly influenced by the IEA to become not only an educational researcher but also an education policymaker. He was well known and respected both on the international and national levels. The model of measuring student achievement and assessment, and of educational research in general, that was first presented in Graenna influenced Zoltán Bathory's former education school, as well as having an impact on student assessment at the University of Szeged. This model is known today as the "behavioural science paradigm" (Kozma, 2001). Moreover, the Graenna seminar also had an impact on the establishment of the Hungarian Educational Research Association (HERA) in 1989. Endre Ballér (1929-2007), who took part in the curriculum development group, did not commence his career at the Education Ministry, nor did he plan curricula there. However, he did manage to establish influential UNESCO and IEA relations, and had an opportunity to travel to developing countries as a curriculum developer. Endre Ballér's contribution to the creation of the first version of National Curriculum (NAT) was inevitable.

Needless to say, all of the participants of the Graenna seminar supported Ballér in carrying out this curriculum development. The creation of the first version of NAT was inevitably influenced by the Graenna seminar and Tyler's concept of the curriculum (Ballér, 1994, p. 358). However, it had another intention as well, and the first version was published in the academic White Paper (1977). The White Paper had an impact on NAT disputes and on educational thinking. Péter Szebenyi (1933-2001), who also contributed to the development of the National Curriculum (NAT), was influenced by the Graenna seminar too (Szebenyi, 1992).

Tamás Kozma was mainly influenced by Havighurst's sociology of education (Havighurst \& Neugarten, 1962). This interpretation of the sociology of education differed from those Hungarian and Eastern European sociological concepts that stressed the importance of social mobility when attempting to research education. Havighurst had a different concept of the sociology of education because he was mainly influenced by Margaret Mead (Mead, 1970), as he interpreted education in the border context of the socialisation process. This approach to the sociology of education stressed the importance of the social 
background variables of student achievement, whereas Hungarian education sociology research mainly focused on official statistics when carrying out social mobility research. For this reason, researching the effects of school districts became part of such research. This variable summarises all of the social influence factors that might have an impact on student achievement, and gives a more detailed explanation of differences in student achievement (Kozma, 1979). Tamás Kozma's continued interest in the sociocultural differences of Hungarian territorial units dates back to this time.

Members of the Hungarian team at the Graenna seminar encountered the IEA's interpretation of education, which was somewhere between basic research and applied education policy research, for the first time. The organisers of the Graenna seminar were successful educational researchers who had experienced how education policy might be influenced and how education reforms might be initiated. A successful education reform, supported by the notions of social democracy, had been carried out in Sweden after the second World War. Those who initiated the IEA and the Graenna seminar gained confidence from this success. The purpose of educational research - which is preferably independent of education policy (the Ministry of Education) - should not only be applied in school practice but also with regard to the education policy that influences school practice. The Hungarian team was influenced by this idea of applied education policy research.

Zoltán Bathory was a good example of someone who started his career as a researcher and ended up as an education policymaker. His role model was Torsten Husén, who worked as a professor all his life. Although Árpád Kiss played a role in influencing education policy and education policymakers, he only managed to reach his goal in the informal context. On the other hand, Zoltán Bathory became a leading education policymaker, and he always managed to associate his name with his education reforms. Endre Ballér's interest in education policy was applied in the preparation of NAT. The NAT disputes also influenced Péter Szebenyi's career, however, as he instead concentrated on different aspects of education policy (such as education advisory). Tamás Kozma was influenced by this commitment to education policymaking when he contributed to educational planning on different levels and on different terms. All in all, the Graenna seminar was extremely influential in all of the participants' academic careers. It was just one moment of the new era of 1960 s education policy, but what a moment! 


\section{References}

Ballér, E. (1994). Tantervelméleti paradigmaváltások a a magyar neveléstörténetben [Changes of Curriculum Paradigms in the Hungarian History of Education]. Educatio, 3(3), 355-66.

Bloom, B. S. et al. (1971). Handbook of Formative and Summative Evaluation of Student Learning. New York: McGrow-Hill.

Coleman, J. S. (1966). Equality of Educational Opportunity. Washington DC: Government Printing Office.

Comber, L. C., \& Keeves, J. P. (1973). Science Education in Nineteen Countries. Stockholm: Almqvist, Wiksell.

Coombs, Ph. H. (1968). Az oktatás világválsága [The World Crisis in Education: The View from the Eighties]. Budapest: Tankönyvkiadó.

Hajtman, B. (1971). Bevezetés a matematikai statisztikába [Introduction to Mathematical Statistics].

Budapest: Akadémiai.

Havighurst, R. J. (1962). Growing Up in River City. New York: Wiley.

Havighurst, R. J. (1966). Education in Metropolitan Areas. Boston: Allyn and Bacon.

Havighurst, R. J., \& Neugarten, B. L. (1962). Society and Education. Boston: Allyn and Bacon.

Husén, T., \& Boalt, G. (1967). Educational Research and Educational Change. Stockholm: Almqvist,

Wiksell.

Husén, T., \& Postlethwaite, N. T. (1988). International Encyclopaedia of Education: Research and

Studies. Oxford: Pergamon Press (Elsevier).

Husén, T. (1969). Talent, Opportunity and Career. Stockholm: Almqvist, Wiksell.

Jensen, A. (1969). How much can we boost IQ and scholastic achievement? Harvard Education

Review, 39(1), 1-133.

Kagan, J., \& Havemann, E. (1968). Psychology: An Introduction. New York etc: Harcourt, Brace.

Kiss, Á. (1977). Müveltség és iskola [Lifelong Learning and the School]. Budapest: Akadémaiai Kiadó.

Kiss, Á. (Ed.) (1970). Ötödik nevelésügyi kongresszus I-II [Fifth Educational Congress]. Budapest.

Kozma, T. (1969). Tudásmérés húsz országban. Beszélgetés T. Neville Postlethwaite-tal [Measuring

Student Achievement in 20 Countries. An Interview with T. Neville]. Postlethwaite Köznevelés, (7),

23-25.

Kozma, T. (1972). Neveléstudományi kutatás és oktatásügyi reform [Educational Research and Education Reform]. Pedagógiai Szemle, 22(1), 90-92.

Kozma, T. (1979). Az iskola mint a tanítás-tanulás szervezeti kerete [Schools as Fields of Teaching and Learning Environments]. In A. Kiss, (pp. 442-79).

Kozma, T. (2001). Paradigmáink [Paradigms]. Iskolakultúra, 11(10), 3-14 .

Mead, M. (1970). Culture and Commitment. New York: The Natural History Press.

Nagy, S. (1966). A didaktika alapjai [Principles of Didactics]. Budapest: Akadémiai.

Pléh, Cs. (1992). Pszichológiatörténet [History of Psychology]. Budapest: Gondolat.

Pukánszky, B., \& Németh, A. (1997). Neveléstörténet [History of Education]. Budapest: Nemzeti 
Tankönyvkiadó.

Szebenyi, P. (1992). Tantervfajták külföldön [Curriculum Types Abroad]. In N. Horánszky (Ed.), Tantervek külföldön. A tantervelmélet forrásai 15, (pp. 355-66). Budapest: Országos Közoktatási Intézet.

Tyler, R. (1970). Basic Principles of Curriculum and Instruction. Chicago: Chicago University Press. Walker, D. A. (1976). The IEA Six Subject Survey. New York: John Wiley.

\section{Biographical note}

TAMás Kozma is emeritus professor (sociology of education) at the Institute of Educational Sciences and president of the Center for Higher Education Research and Development, both at The University of Debrecen (Hungary). He has studied theology, history and education in Budapest, Szeged (Hungary) and Cluj (Romania). He has received his $\mathrm{PhD}$ from The University of Szeged, his C.Sc (Candidate of Sciences) and D.Sc (Doctor of Sciences) from The Hungarian Academy of the Sciences, and his habilitation from his present university. He was the director of the Hungarian Institute for Educational Research (Budapest) between 1990-2000 which he still serves as a scientific adviser.

ZoLTÁN Tözsér received Master’s degrees with honors in history and in education. He has teacher certifications in both subjects. Later he studied in the Educational Doctoral Program of the Doctoral School of Humanities at the University of Debrecen, Hungary. He has been the researcher and manager of the Center for Higher Education Research and Development (CHERD-Hungary). He has published studies and book reviews in Hungarian and in English and has given presentations in international and Hungarian conferences. He was granted the ECER scholarship of the European Educational Research Association (EERA) three times and the British Educational Scholarship (BERA) in 2012. Zoltan has considerable international experience because he studied at the Danish School of Education at Åarhus University. In 2012 he was granted an American scholarship at Indiana University Bloomington, USA as a visiting scholar. 